\title{
A Study of EFL Teachers' Locus of Control and Self-regulation and the Moderating Role of Self- efficacy
}

\author{
Mohammad Taghi Monshi Toussi \\ Department of English Language, Mashhad Branch, Islamic Azad University, Iran \\ Email: m_toussi@mshdiau.ac.ir \\ Afsaneh Ghanizadeh (Corresponding author) \\ Department of English Language, Mashhad Branch, Islamic Azad University, Iran \\ Email: ghanizadeh@mshdiau.ac.ir; ghanizadeafsane@yahoo.com
}

\begin{abstract}
The present study investigated the relationship between EFL teachers' locus of control and selfregulation and the moderating role of self-efficacy. To empirically investigate the theorized relationship between self-regulation and locus of control, 63 English teachers were selected according to a convenience sampling from different language institutes in Mashhad. The participants were asked to complete the' Teacher Self-Regulation Scale' as well as the 'Teacher Locus of Control Scale'. The data supported the theoretical expectation of a linkage between self-regulation and locus of control. The results indicated a significant relationship between teachers' self-regulation and internal locus of control. It was found that about $48 \%$ of the variation in teacher self-regulation can be explained by taking their internal LOC into account. Subsequent data analyses indicated that among the components of self-regulation, 'mastery goal orientation', and 'intrinsic interest' have the highest correlations with teacher locus of control. The findings also illustrated that teacher self-efficacy had no significant impact on the relationship between self-regulation and locus of control. This suggests that regardless of the teacher self-efficacy level, a teacher self-regulation is related to his/her internal locus of control. The results derived from the present study should encourage teacher educators to take advantage of this relationship by providing EFL teachers with programs and experiences for developing effective paths for enhancing teacher self-regulatory skills as well as their internal tendencies and perceptions.
\end{abstract}

Index Terms-EFL teachers, locus of control, self-efficacy, self-regulation

\section{INTRODUCTION}

The issue of individuals' control over fate and life events has long been the topic of debate. The controversy pivoted around the notions of fate or free will, whether life events that affect individuals are in their control or out of their hands. In a related vein, in recent decades educational researchers and theorists have displayed increased interest in attributional and related cognitive theories of control. One of the pertinent notions is the locus of control perceptions (LOC) derived from Rotter's (1966) social learning theory which contended that individual differences existed as to perceived responsibility for one's own actions and the individual's sense of personal control and reinforcement. LOC is characteristically measured on an internal-external continuum. To the extent that a person's LOC is external, s/he will tend to perceive reinforcements as being the result of other people, luck, and circumstances beyond personal control. Internal LOC is associated with individual's perception of having more control over life circumstances as well as more personal responsibility for outcomes.

Substantial body of research in educational psychology has been conducted in examining the association of LOC with academic achievement. What has emerged from almost all these studies revealed that students with internal LOC exert more effort, responsibility and persistence toward their learning goals (Findley \& Cooper, 1983).

The tenets pertained to LOC in explaining behavior and achievement tend to generalize to teachers. Teacher LOC refers to teachers' perceptions of personal control or responsibility for student achievement. Previous research has consistently demonstrated that teaching effectiveness is positively linked to teachers' internal tendencies (e.g. Shermen \& Giles, 1981; Findley \& Cooper, 1983). Rose and Medway (1981) indicated that internal teachers tended to produce higher achieving students by engaging students in more appropriate on-task behavior resulted from executing a more controlled learning context. It also appears that internal LOC is associated with other intrinsic and motivational factors, including self-efficacy (Greenwood, Olejnik, \& Parkey, 1990; Gaziel, 2008); self-esteem and higher self-evaluations (Burns, 1979); motivation (Anderson, Hattie \& Hamilton, 2005); and attitude (Smith, 1997). Despite the bulk of research examining the linkage of teachers' internal LOC with skills and factors conducive to effectiveness, there are hardly any documented studies investigating the relationship between teachers' LOC and an intrinsically derived construct which is critical in professional development, i.e., self-regulation. 
The present study sets out to explore the relationship of Iranian EFL teachers' LOC with their self-regulation. It also seeks to examine whether teacher self-efficacy moderates the relationship between LOC and self-regulation.

\section{REVIEW OF THE RELATED LITERATURE ON LOC}

Locus of control (LOC) is a well-known cognitive-behavioral psychological attribute describing a person's characteristic way of perceiving the world and indicating the extent of control individuals perceive they have over the expectancies of reinforcement or outcomes in their lives (Rotter, 1966). Rotter defined locus of control as a generalized expectancy of internal (self-initiated change orientation) versus external control (change attributed to a source or power outside of the person) over behavior outcomes. In other words, individuals with internal LOC orientation believe that the ability to influence outcomes resides within themselves and is the direct result of their efforts, personality strength, and intensions. On the other hand, those with external LOC orientation attribute outcomes to forces beyond their control (Rotter, 1966). These individuals tend to appraise life events by looking for another individual or circumstance to hold accountable for undesirable outcomes (Joe, 1971).

The construct of LOC and its influence on human behavior has been increasingly integrated into educational studies. A plethora of studies substantiated the contention that internal LOC is essentially associated with positive characteristics and achievement. Findley and Cooper (1983) conducting a comprehensive literature research on nearly 100 studies verified the link between LOC and academic achievement. Williams and Burden (1997) pointed out that students with high internal LOC exhibit strong tendencies to seek information, are active and assertive, and are inclined toward exploratory learning. Conversely, students with external LOC are passive, compliant, non-exploratory, and inattentive (p. 102). Furthermore, they tend to be less motivated to attain learning goals since they believe unsuccessful performance is their fate and out of their hands (Bender, 1995). Other studies demonstrated the association of internal LOC with reflective thinking (Norton, 1997), stress control (Abouserie, 1994), self-efficacy and self-worth (Harsch, 2008), and problem-focused copying strategies (Butler-Sweeney, 2007). LOC has also been found to have an impact on students' responses to outside influence or control. Baron and Ganz (1972) indicated individuals with external LOC were more responsive than those with internal LOC to positive verbal feedback (cited in Moore, 2006). Pines (1973) found that externally controlled people seemed to be more attentive to and affected by the interpersonal characteristics of the person giving the positive feedback than were internally controlled people (cited in Moore, 2006).

Likewise, investigating the possible relations of teacher LOC with factors and abilities associated with effective teaching has become a paramount inquiry for educational scholars and researchers. Brookover and Lezotte (1979) defined teacher LOC as teachers' perceptions of personal control over or responsibility for student performance; whether they see students' achievement as a consequence of their own actions and under their personal control or not. Studies targeted at the relationship between teacher LOC and students' achievement have inclusively indicated that teachers with internal LOC appear to have classes of higher achieving students than external teachers (e.g. Murray \& Staebler, 1974; Rose \& Medway, 1981). Czubaj (1996) classified LOC as one major construct of motivation, and concluded that internal LOC tended to reduce teacher stress and enhance motivation. It has also been shown that internal LOC is associated with reflectivity. Norton (1997) noted that teacher with internal LOC orientations are more reflective teachers in that they are more responsive to the educational and affective needs of every individual student, and constantly review and appraise the instructional goals and aims. Bulus' (2011) study revealed that prospective teachers' high level of internal LOC plays a role in mastery goal orientation (goals to improve competence in teaching and master the teaching task) and academic achievement.

Cheng (1994) identified LOC as a powerful indicator of teachers' job attitudes. According to him,

Teachers with a belief in internal control tend to have a more positive job attitude in terms of organizational commitment, intrinsic satisfaction, extrinsic satisfaction, social satisfaction, influence satisfaction, role clarity, and feeling of job challenge. They also tend to have more positive perceptions of the school organization in terms of principal's leadership, organizational structure, teachers' social norms, and organizational culture and effectiveness. (cited in Lorenz, 2000, p.19)

\section{REVIEW OF THE RELATED LiterATURE ON SELF-REGULATION}

Self-regulation is defined as "self-generated thoughts, feelings, and actions that are planned and cyclically adapted to the attainment of personal goals" (Zimmerman, 2000, p. 14). According to Pintrich (1999), self-regulation comprises three general classes of strategies: (a) cognitive learning strategies, (b) metacognitive or self-regulatory strategies to control cognition, and (c) resource management strategies. Cognitive and metacognitive strategies include rehearsal, elaboration, and organizational strategies as well as critical thinking and self-regulation. Basic rehearsal strategies involve reciting or repeating items in a list. Activation of information in working memory entails application of these strategies which appear to influence attention and encoding processes. Elaboration strategies including paraphrasing, summarizing, and analogy-making, play crucial role in storing information in long-term memory by creating internal connections between items. Via organizational strategies, learners select appropriate information and impose structure on the learned materials. Critical thinking involves a variety of skills such as identifying the source of information, reflecting on whether that information is consistent with their prior knowledge, and making critical evaluations (Linn, 
2000). Self-regulation strategies refer to awareness, knowledge and control of cognition and include planning, monitoring, and regulating.

Theories and practices associated with self-regulation have been applied to educational settings and school learning, leading to the development of self-regulated learning theory. Self-regulation of learning is a process that requires students to get proactively involved in their personal, behavioral, motivational, and cognitive learning endeavors in order to accomplish important and valuable academic goals (Zimmerman, 1998). Self-regulated learning theory contends that self-regulation develops across four levels: observational, imitative, self-controlled, and self-regulated levels (Zimmerman, 2000). Observational and imitative levels, relying on external social factors, concentrate on modeling and social guidance, respectively. The last two levels derive from internal skills. At the self-controlled level, learners create internal standards for acceptable performance and become self-reinforcing via positive self-talk and feedback. At the self-regulatory level, individuals develop self-efficacy beliefs, as well as higher-order cognitive strategies, that enable them to self-regulate their learning.

Empirical studies indicated a significant relationship between academic success and the use of regulatory skills and an understanding of how to use these skills (Cross \& Paris, 1988; Zimmerman \& Schunk, 2001). In a similar vein, Zimmerman (1990) noted that self-regulated learners proactively seek out opportunities to learn and self-initiate activities designed to promote learning outcomes. Since research has indicated students' use of self-regulatory behaviors to be critical for academic achievement, it is plausible that the teachers' use of self-regulatory behaviors would positively influence teacher practices. According to Delfino, Dettori, and Persico (2010) learning to be self-regulated is crucial for teachers in order to deal with the complexity of the teaching role, which encompasses individual and social aspects. From personal perspective, teachers should equip themselves with self-regulation skills in order to not only follow various goals and tasks, but also sustain and foster their motivation, commitment and effectiveness. From social perspective, self-regulation assists teachers to construct instructional strategies based on students' specific goals, and "to adjust to the ever more frequent curricular revisions required by the fast pace of technological and cultural change" (Delfino, Dettori, \& Persico, 2010, p. 300). To create opportunities for insightful instruction, teachers not only need a solid base of content area knowledge along with classroom management skills, but also have to scrutinize their beliefs, motivation, and self-regulatory factors associated with teaching and learning (Dembo, 2001). Indeed, as Randi (2004) maintained from social cognitive perspective, effective teachers are self-regulated agents who can activate their beliefs to take appropriate actions leading to successful accomplishment of their professional tasks. Viewing from another perspective, it seems plausible to presume teachers who lack self-regulatory skills will find it difficult or even impossible to construct the self-regulation of their students.

In the domain of L2 education, it has been reported that teachers who are more self-regulated can better manifest teaching effectiveness (Monshi toussi, Boori \& Ghanizadeh, 2011). In other words, teachers' self-regulatory skills tend to have a positive role in successful accomplishment of their professional tasks. In a similar vein, teachers' selfregulation has been found to be associated with their sense of self-efficacy beliefs. Ghonsooly and Ghanizadeh (2011) revealed that the more EFL teachers equip themselves with self-regulatory skills, the more capable they judge themselves in their teaching practice.

\section{PURPoSe OF THE STUDY}

The major purpose of the present study is to empirically examine the hypothesized association between teachers' LOC and their self-regulation. The study also seeks to investigate the moderating effect of teacher self-efficacy on the relationship of LOC and self-regulation. To this end, the following research questions were posed and investigated in the present study:

1) Is there any relationship between teacher LOC and their self-regulation?

2) Among the components of self-regulation which one(s) have/has the highest correlation with teacher LOC?

3) What percent of variability in teacher LOC can be explained by taking self-regulation into account?

4) As a moderator factor, does teacher self-efficacy play any significant role in the relationship between teachers' internal LOC and self-regulation?

\section{METHOD}

\section{A. Participants}

A sample of convenience was used for this study. The population sample consisted of 63 Iranian EFL teachers who were teaching English in private institutes in Mashhsd, a city in north-east of Iran between July and October 2010. There were no requirements other than that the participants be currently teaching an English course during the summer semester of 2010. There were 43 females and 20 males; their age varied from 21 to 42 years old $(M=26.31, S D=4.05)$ and their teaching experience varied from 1 to 19 years $(\mathrm{M}=4.16, \mathrm{SD}=3.86)$.

\section{B. Instruments}

1. Teacher Self-Regulation Scale (TSRS) 
To assess teacher self-regulation, the researcher utilized the 'Teacher Self-Regulation Scale (TSRS)', designed and validated by Yesim, Sungur \& Uzuntiryaki (2009). It was developed based on Zimmerman's self -regulation model and semi-structured interviews with pre-service and in-service teachers; and consists of 40 items on a 6 point Likert scale ranging from 'strongly disagree' to 'strongly agree'. One item was also included as a filler item which was not used in further analyses. Confirmatory factor analysis yielded the following nine factors. (See Table 1)

TABLE 1.

NINE FACTORS OF TSRS ALONG WITH THE CORRESPONDING DESCRIPTIONS.

\begin{tabular}{|l|l|}
\hline Factor & Description \\
\hline 1. Goal setting & Process of establishing objectives to guide actions during instruction \\
\hline 2. Intrinsic interest & Beliefs concerning personal interest in the profession \\
\hline $\begin{array}{l}\text { 3. Performance } \\
\text { goal orientation }\end{array}$ & $\begin{array}{l}\text { Goals to do better than others as a teacher and to have others } \\
\text { believe in one's competence }\end{array}$ \\
\hline $\begin{array}{l}\text { 4. Mastery goal } \\
\text { orientation }\end{array}$ & $\begin{array}{l}\text { Goals to improve competence in teaching and master the teaching } \\
\text { task against self-set standards }\end{array}$ \\
\hline $\begin{array}{l}\text { 5. Self-instruction } \\
\text { Process of monitoring one's own performance in teaching and } \\
\text { making instructional changes when necessary }\end{array}$ \\
\hline control & $\begin{array}{l}\text { Strategies for controlling and regulating affect, mood, and } \\
\text { emotions }\end{array}$ \\
\hline 7. Self-evaluation & $\begin{array}{l}\text { Process of evaluating current teaching performance by } \\
\text { comparing it with previously established goals and past performance }\end{array}$ \\
\hline 8. Self-reaction & Affective responses following a teaching performance \\
\hline 9. Help-seeking & $\begin{array}{l}\text { Getting help from others to resolve problems encountered in } \\
\text { teaching process }\end{array}$ \\
\hline
\end{tabular}

Scores on the 40 items were averaged to form an overall indicator of the teachers' self-regulation, defined by Yesim, Sungur \& Uzuntiryaki (2009) "as teachers' own self-regulated strategies, which they use during lessons" (p. 354). In this study, the total reliability of the scale, estimated via Cronbach's alpha, was 0.79 .

2. Teacher Locus of Control Scale (TLC)

To determine teacher LOC, the study utilized the 'Rose and Medway's (1981) Teacher Locus of Control (TLC) scale'. It is a 28 -item forced-choice scale which requires teachers to assign responsibility for student successes or failures by choosing between two competing explanations for the situations described. Half the items on the $T L C$ describe situations of student success while the other half describe student failure. For each success situation, one explanation attributes the positive outcome internally to the teacher (I+) while the other assigns responsibility outside the teacher, usually to the students. Similarly, for each failure situation, one explanation gives an internal teacher attribution (I-) while the other blames external factors (Rose \& Medway, 1981).

3. Teachers' Sense of Efficacy Scale (OSTES)

To determine teacher's self-efficacy, the study employed the Teachers' Sense of Efficacy Scale designed by Tschannen-Moran and Woolfolk Hoy, due to its comprehensiveness, integrity, and ease of administration. Teachers' Sense of Efficacy Scale, also called Ohio State Teacher Efficacy Scale (OSTES), includes two versions: long form (including 24 items) and short form (including 12 items). In the current study the long form was applied which includes three subscales: 1) efficacy in student engagement, 2) efficacy in instructional strategies, and 3) efficacy in classroom management. Each subscale loads equally on eight items, and every item is measured on a 9-point scale anchored with the notations: "nothing, very little, some influence, quite a bit, a great deal." This scale seeks to capture the multifaceted nature of teachers' efficacy beliefs in a concise manner, without becoming too specific or too general.

The total reliability and the reliability of each individual factor - reported by Tschannen-Moran and Woolfolk Hoy (2001) - are depicted in table 2 (See Table 2).

TABLE 2.

RELIABILITY REPORTS OF OSTES

\begin{tabular}{|l|l|l|l|}
\hline & Mean & SD & Alpha \\
\hline OSTES & 7.1 & .94 & .94 \\
\hline F 1 & 7.3 & 1.1 & .87 \\
\hline F 2 & 7.3 & 1.1 & .91 \\
\hline F 3 & 6.7 & 1.1 & .90 \\
\hline
\end{tabular}

In this study, the total reliability of the questionnaire was calculated via Cronbach's alpha which was found to be 0.78 .

\section{Data Collection}

The teachers in the aforementioned institutes were distributed TSRS, TLC, and OSTES questionnaires which they completed and delivered back to the researcher. The questionnaires were coded numerically and they were asked not to write their names. The participants were assured that their identities and responses would be kept confidential.

\section{Data Analysis}


To ensure the normality of the distribution, descriptive statistics was employed. To determine the relationship between LOC and self-regulation, a Pearson product-moment correlation was conducted to the data. To find out which components of self-regulation might have more predictive power in predicting LOC, a multiple regression analysis was run. To determine the role of self-efficacy as a moderating factor in the relationship between internal LOC and selfregulation among EFL teachers, a standard multiple regression analysis was run.

\section{REsults}

Table 3 summarizes the descriptive results of the instruments- the Teacher Self-Regulation Scale (TSRS), the Teacher Locus of Control Scale (TLC), and the Teachers' Sense of Efficacy Scale (OSTES) - utilized in this study. (See Table 3)

TABLE 3.

DESCRIPTIVE STATISTICS OF TSRS, TLC, AND OSTES

\begin{tabular}{|l|l|l|l|l|l|l|}
\hline \multicolumn{2}{|c|}{} & N & Minimum & Maximum & Mean & Std.Deviation \\
\hline TSRS & 63 & 120 & 240 & 179 & 24.41 \\
\hline \multirow{2}{*}{ TLC } & Internal & 63 & 6 & 21 & 12.79 & 3.61 \\
\cline { 2 - 7 } & External & 63 & 4 & 19 & 12.19 & 3.62 \\
\hline OSTES & 63 & 120 & 205 & 161 & 20.01 \\
\hline
\end{tabular}

To investigate the relationship between EFL teachers' internal and external LOC and their self-regulation, a Pearson product-moment correlation was applied. The results of correlation revealed that there is a significant correlation between internal LOC and self-regulation $(r=0.69, \mathrm{p}<0.05)$. (See Table 4)

TABLE 4.

THE RESULTS OF CORRELATION BETWEEN INTERNAL AND EXTERNAL LOC AND SELF-REGULATION

\begin{tabular}{|l|l|}
\hline & Total self-regulation \\
\hline Internal LOC & $0.69 *$ \\
\hline External LOC & $-0.69 *$ \\
\hline
\end{tabular}

It was also found that there is a significant relationship between internal LOC and the subscales of self-regulation scores as follow: internal LOC and F1 $\left(\mathrm{r}=0.42^{*}, \mathrm{p}<.05\right), \mathrm{F} 2\left(\mathrm{r}=0.61^{*}, \mathrm{p}<.05\right), \mathrm{F} 3\left(\mathrm{r}=0.47^{*}, \mathrm{p}<.05\right), \mathrm{F} 4\left(\mathrm{r}=0.55^{*}\right.$, $\mathrm{p}<.05), \mathrm{F} 5\left(\mathrm{r}=0.53^{*}, \mathrm{p}<.05\right), \mathrm{F} 6\left(\mathrm{r}=0.52^{*}, \mathrm{p}<.05\right), \mathrm{F} 7\left(\mathrm{r}=0.44^{*}, \mathrm{p}<.05\right), \mathrm{F} 8\left(\mathrm{r}=0.49^{*}, \mathrm{p}<.05\right), \mathrm{F} 9\left(\mathrm{r}=0.38^{*}, \mathrm{p}<.05\right)$,

To analyze the data further, regression analysis was conducted. The results indicated that teacher internal LOC is a positive predictor of the dependant variable (self-regulation). (See Table 5)

TABLE 5.

THE RESULTS OF REGRESSION ANALYSIS FOR LOC AND SELF-REGULATION

\begin{tabular}{|c|c|c|c|c|c|c|}
\hline \multirow{2}{*}{\multicolumn{2}{|c|}{ Model }} & \multicolumn{2}{|c|}{ Unstandardized Coefficients } & \multirow{2}{*}{$\begin{array}{c}\begin{array}{c}\text { Standardized } \\
\text { Coefficients }\end{array} \\
\text { Beta }\end{array}$} & \multirow[b]{2}{*}{$\mathbf{t}$} & \multirow[b]{2}{*}{ Sig. } \\
\hline & & B & Std. Error & & & \\
\hline \multirow[t]{2}{*}{1} & (Constant) & -5.658 & 2.466 & & -2.294 & .025 \\
\hline & Self-regulation & .103 & .014 & .695 & 7.549 & .000 \\
\hline
\end{tabular}

a. Dependent Variable: Internal LOC

Table 5 illustrates the model summary statistics. The results revealed that the model containing the internal LOC can predict 48 percent of the teacher self-regulation. The $\mathrm{R}$ value is 0.69 which indicates the correlation coefficient between self-regulation and internal LOC. Its square value is 0.48 . It indicates that about $48 \%$ of the variation in teacher selfregulation can be explained by taking their internal LOC into account. (See Table 6)

TABLE 6.

R SQUARE TABLE FOR INTERNAL LOC AS THE PREDICTOR OF SELF-REGULATION

\begin{tabular}{|l|l|l|l|l|}
\hline Model & R & R Square & Adjusted R Square & Std. Error of the Estimate \\
\hline 1 & $.695^{\mathrm{a}}$ & .483 & .475 & 2.61743 \\
\hline
\end{tabular}

To determine the role of self-efficacy as a moderator in the relationship between LOC and self-regulation among teachers, a standard multiple regression analysis was run. In so doing, three models were considered. In the first model self-regulation, in the second model self-regulation and self-efficacy and in the third model self-regulation, self-efficacy and the interaction between these two factors were regarded as independent variables. Table 7 is the ANOVA table of regression. The extent of F-values and the quantities of the associated p-values $(p<0.05)$ suggest the considered models are significant. 
TABLE 7:

THE ANOVA TABLE OF REGRESSION

\begin{tabular}{|ll|l|l|l|l|l|}
\hline Model & & Sum of Squares & df & Mean Square & F & Sig. \\
\hline 1 & Regression & 390.411 & 1 & 390.411 & 56.987 & $.000^{\mathrm{a}}$ \\
& Residual & 417.907 & 61 & 6.851 & & \\
& Total & 808.317 & 62 & & & \\
\hline 2 & Regression & 396.018 & 2 & 198.009 & 28.815 & $.000^{\mathrm{b}}$ \\
& Residual & 412.300 & 60 & 6.872 & & \\
& Total & 808.317 & 62 & 3 & 19.698 & $.000^{\mathrm{c}}$ \\
& Regression & 404.476 & 3 & 6.845 & & \\
& Residual & 403.842 & 59 & 62 & &
\end{tabular}

b. Predictors: (Constant), self-regulation, self-efficacy

c. Predictors: (Constant), self-regulation, self-efficacy, self-regulation x self-efficacy

$$
\text { d. Dependent Variable: Internal LOC }
$$

Table 8 illustrates that, among different variables involved in the models, only the p-values of self-regulation are less than 0.05 ; therefore, the existence of this factor is necessary in the models.

TABLE 8.

THE RESULTS OF REGRESSION ANALYSIS FOR SELF-EFFICACY AS A MODERATOR

\begin{tabular}{|c|c|c|c|c|c|c|}
\hline & & \multicolumn{2}{|c|}{ Unstandardized Coefficients } & \multirow{2}{*}{$\begin{array}{l}\text { Standardized Coefficients } \\
\text { Beta }\end{array}$} & \multirow[b]{2}{*}{$\mathbf{t}$} & \multirow[b]{2}{*}{ Sig. } \\
\hline \multicolumn{2}{|c|}{ Model } & B & Std. Error & & & \\
\hline \multirow[t]{2}{*}{1} & (Constant) & -5.658 & 2.466 & & -2.294 & .025 \\
\hline & Self-regulation & .103 & .014 & .695 & 7.549 & .000 \\
\hline \multirow[t]{3}{*}{2} & (Constant) & -5.000 & 2.575 & & -1.941 & .057 \\
\hline & Self-regulation & .117 & .021 & .793 & 5.574 & .000 \\
\hline & Self-efficacy & -.019 & .021 & -.128 & -.903 & .370 \\
\hline \multirow[t]{4}{*}{3} & (Constant) & 10.498 & 14.177 & & .741 & .462 \\
\hline & Self-regulation & .028 & .083 & .189 & .337 & .737 \\
\hline & Self-efficacy & -.115 & .088 & -.760 & -1.298 & .199 \\
\hline & Self-regulation x self-efficacy & .001 & .000 & 1.164 & 1.112 & .271 \\
\hline
\end{tabular}

As demonstrated in table 9, we see that $R$ Square Change is 0.007 when the moderator variable is added (model 2). This change is not significant $(F=0.81, p=0.37$ ). When interaction variable is added (model 3$)$ to the predictor and moderator variables, $R$ Square Change is 0.10 . This change in not significant either $(F=1.23, p=0.27)$. This indicates that our presumed moderator (self-efficacy) does not moderate the effect of the predictor (self-regulation) on the dependent variable (internal LOC).

TABLE 9.

R SQUARE TABLE FOR SELF-REGULATION AND SELF-EFFICACY AS THE PREDICTORS OF TEACHERS' INTERNAL LOC

\begin{tabular}{|c|c|c|c|c|c|c|c|c|c|}
\hline \multirow[b]{2}{*}{ Model } & \multirow[b]{2}{*}{$\mathbf{R}$} & \multirow[b]{2}{*}{ R Square } & \multirow[b]{2}{*}{ Adjusted R Square } & \multirow{2}{*}{$\begin{array}{l}\text { Std. Error of the } \\
\text { Estimate }\end{array}$} & \multicolumn{5}{|l|}{ Change Statistics } \\
\hline & & & & & R Square Change & F Change & df1 & df 2 & Sig. F Change \\
\hline 1 & $.695^{\mathrm{a}}$ & .483 & .475 & 2.61743 & .483 & 56.987 & 1 & 61 & .000 \\
\hline 2 & $.700^{\mathrm{b}}$ & .490 & .473 & 2.62138 & .007 & .816 & 1 & 60 & .370 \\
\hline 3 & $.707^{\mathrm{c}}$ & .500 & .475 & 2.61625 & .010 & 1.236 & 1 & 59 & .271 \\
\hline
\end{tabular}

a. Predictors: (Constant), self-regulation

b. Predictors: (Constant), self-regulation, self-efficacy

c. Predictors: (Constant), self-regulation, self-efficacy, self-regulation x self-efficacy

\section{DISCUSSION}

The present study examined the relationship between Iranian EFL teachers' self-regulation and locus of control. As the results indicated there is a positive relationship between the two variables in question. In other words, teachers who possess higher levels of self-regulatory skills tend to attribute success and failure in their profession to internal factors. The statistical significance of this finding supports the key theoretical assumptions of the association between self- 
regulation and internal locus of control as contended by educational scholars. For instance, Zimmerman (1990) maintained that self-regulated learners view acquisition as a controllable process and accept greater responsibility for their achievement outcomes. Skinner and Greene (2008) argued that control beliefs have two main functions in shaping control processes: (1) when preparing to take on an activity, expectations of control have a regulatory function in that they shape how people approach and engage in the task; and (2) following an action-outcome episode, they have an interpretative function, in that they help translate the meaning of the experience for future control.

The findings of the present study can also be interpreted from the common sense perspective. As stated earlier, teachers who believe that they are competent to effectively influence student achievement and performance are considered to have internal control, whereas teachers who believe that the environment has more influence on student learning than their own teaching abilities are considered to have external control. Here it seems plausible to presume teachers who routinely exert effort to devise appropriate instructional materials and motivate students to do better are required to regularly monitor and regulate their actions and thoughts, in comparison with teachers who believe student achievement is attributable to external factors which are not under their control.

As indicated earlier, among the components of self-regulation, intrinsic interest and mastery-goal orientation were found to have the highest correlations with internal LOC. With the significant correlation to intrinsic interest, it would appear that teachers who have personal interest in their profession exhibit more internally driven locus of control for student performance. This can plausibly be interpreted from commonsense perspective, given that both of these constructs are intrinsically oriented. This finding is also consistent with the notion that individuals engage in attributional inference to judge their intrinsic motivation (Lindzey, Gilbert \& Fiske, 1998). Deci and Ryan (2000) argued that the extent individuals perceive the events as being the result of their actions and under their control is partly associated with their intrinsic motivation, or sense of choosing to engage in that activity. In a similar vein, Elliot and Dweck (2005) noted that those with an internal locus will often use intrinsic motivation, which is person centered and comes from within an individual.

The relationship between internal LOC and mastery goal orientation-goals to improve competence in teaching and master the teaching task against self-set standards - implies that teachers' concern over the mastery of teaching practices tend to promote their perception of having more control over student achievement. This finding corroborates previous studies verifying association between LOC and goal orientation. For instance, Pintrich \& De Groot, (1990) indicated that students with mastery goal orientation try to acquire knowledge to learn and increase their competence for self development and believe that effort is the cause of success or failure. These individuals were also found to take more responsibility for their success or failure (Seifert, 1995). In the domain of teachers, Bulus (2011) repoeted that prospective teachers' high level of internal LOC plays a role in their mastery goal orientation and students' academic achievement.

The last research question aimed at investigating the role of self-efficacy as a moderating factor in the relationship between teachers' internal LOC and self-regulation. The findings illustrated the presumed moderator had not a significant impact on the relationship between teachers' internal LOC and self-regulation. This suggests that regardless of self-efficacy, the teacher internal LOC is related to his/her level of self-regulation. Hence, it can be argued that selfregulation is a significant predictor of internal LOC even after controlling for the effect of self-efficacy.

The above-mentioned conclusions derived from the present study should encourage teacher educators, administrators, and policy makers to take advantage of the relationship between LOC and self-regulation by providing EFL teachers with preparation programs and experiences that help them self-regulate their teaching practices. In so doing there is opportunity to promote teachers' internal LOC, as well. This in turn is expected to result in effective learning and teaching, since, as stated earlier, teacher internal LOC is a key determinant of student achievement and motivation. These programs are recommended to pinpoint effective paths for developing intrinsic interest and mastery goal orientation among all teachers irrespective of their level of self-efficacy.

\section{REFERENCES}

[1] Abouserie, R. (1994). Sources and Levels of Stress in Relation to Locus of Control and Self Esteem in University Students. Educational Psychology: An International Journal of Experimental Educational Psychology, 14(3), 323-331.

[2] Anderson, A., Hattie, J., \& Hamilton, R.J. (2005). Locus of control, self-efficacy, and motivation in different schools: Is moderation the key to success? Educational Psychology, 25(5), 517.

[3] Baron, R. M., \& Ganz, R. L. (1972). Effects of locus of control and type of feedback on the task performance of lower-class black children. Journal of Personality and Social Psychology, 21, 124-130.

[4] Bender, W. N. (1995). Learning disabilities: Characteristics, identification, and teaching strategies. (2nd Ed.). Needham Heights: Allyn \& Bacon.

[5] Brookover, W., \& Lezotte, L. (1979). Changes in school characteristics coincident with changes in student achievement. East Lansing: Michigan State University, Institute for Research on Teaching.

[6] Bulus, M. (2011). Goal Orientations, Locus of Control and Academic Achievement in Prospective Teachers: An Individual Differences Perspective. Kuram ve Uygulamada Egitim Bilimleri, 41(2), 110-122.

[7] Burns, R., (1979). The self-concept: Theory, measurement, development and behavior. London: Longman.

[8] Butler-Sweeney, J. (2007). The relationship among locus of control, copying style, self-esteem, and cultural identification in female adolescents. Unpublished Doctoral Dissertation. University of Seton Hall. 
[9] Cheng, Y.C. (1994). Locus of control as an indicator of Hong Kong teachers' job attitudes and perceptions of organizational characteristics. Journal of Educational Research, 87 (3), 80-188.

[10] Cross, D.R., \& Paris, S.G. (1988). Developmental and instructional analyses of children's metacognition and reading comprehension. Journal of Educational Psychology, 80, 131- 142.

[11] Czubaj, C. (1996). Maintaining teacher motivation. Education, 116 (3), 372-378.

[12] Deci, E. L., \& Ryan, R. M. (2000). The "what" and "why" of goal pursuits: Human needs and the self-determination of behavior. Psychological Inquiry, 11, 227-268.

[13] Delfino, M., Dettori, G., \& Persico, D. (2010). An online course fostering self-regulation of trainee teachers. Psicothema, 22(2), 299-305.

[14] Dembo, M. H. (2001). Learning to teach is not enough-Future teachers also need to learn how to learn. Teacher Education Quarterly, 28, 23-35.

[15] Elliot, A. J., \& Dweck, C. S. (Eds.). (2005). Handbook of competence and motivation. New York: Guilford.

[16] Findley, M.J., \& Cooper, H.M. (1983). Locus of control and academic achievement: a literature review. Journal of Personality and Social Psychology, 44 (2). 419-27.

[17] Gaziel, H.H. (2008). Teacher sense of efficacy, locus of control, perceived organizational patterns, and attitudes toward educational innovations. Interscience $M R, 1(2), 83-94$.

[18] Ghanizadeh, A. (2011). An investigation into the relationship between self-regulation and critical thinking among Iranian EFL teachers. The Journal of Technology \& Education, 5(3), 213-221.

[19] Ghonsooly, B., \& Ghanizadeh, A. (2011): Self-efficacy and self-regulation and their relationship: a study of Iranian EFL teachers, The Language Learning Journal, http://dx.doi.org/10.1080/09571736.2011.625096

[20] Greenwood, G., Olejnik, S., \& Parkey, F. (1990). Relationships between four teacher efficacy belief patterns and selected teacher characteristics. Journal of Research and Development in Education, 23 (2), 102-106.

[21] Harsch, D, N. (2008). The role of self-efficacy, locus of control, and self-handicapping in dissertation completion. Unpublished Doctoral Dissertation. University of Akron.

[22] Joe, V.A. (1971). Review of the internal-external control construct as a personality variable. Psychological Reports, 28, 619640.

[23] Lindzey, G., Gilbert, D., \& Fiske, S.T. (1998). The Handbook of Social Psychology. Oxford: Oxford University Press.

[24] Linn, M. C. (2000). Designing the knowledge integration environment. International Journal of Science Education, 22(8), 781-796.

[25] Lorenz, J.R. (2000). A study of early childhood preservice teachers' locus of control and self concept as compared to their approach to discipline. Unpublished Doctoral Dissertation. University of Wisconsin-Stout.

[26] Monshi Toussi, M., Boori. A., \& Ghanizadeh. A. (2011). The role of EFL teachers' self-regulation in effective teaching. World Journal of Education, 1(2), pp. 39-48.

[27] Moore, M. M, (2006). Variations in Test Anxiety and Locus of Control Orientation in Achieving and Underachieving Gifted and Nongifted Middle School Students. Unpublish Doctoral Dissertation, University of Connecticut.

[28] Murray, H., \& Staebler, B. (1974). Teachers' locus of control and student achievement gains. Journal of School Psychology, 12, 305-309.

[29] Norton, J.L. (1997). Locus of control and reflective thinking in preservice teachers. Education, 117(3), 401-410.

[30] Pines, H. A. (1973). An attributional analysis of locus of control orientation and source of informational dependence. Journal of Personality and Social Psychology, 26, 262-272.

[31] Pintrich, P.R. (1999). The role of motivation in promoting and sustaining self-regulated learning. International Journal of Educational Research, 31, 459-470. http://dx.doi.org/10.1037/0022-0663.82.1.33

[32] Pintrich, P., \& De Groot, E. (1990). Motivational and selfregulated learning components of classroom academic performance. Journal of Educational Psychology, 82, 33-40.

[33] Rose, J., \& Medway, F. (1981). Measurement of teachers' beliefs in their control over student outcome. Journal of Educational Research, 74 (3), 185-190.

[34] Rotter, J. (1966). Generalized expectancies for internal versus external control of reinforcement. Psychological Monograph, 80 (1) (whole No.609).

[35] Seifert, T. L. (1995). Academic goals and emotions: A test of two models. The Journal of Psychology, 129, 543-552.

[36] Skinner, E., \& Greene, T. (2008). Perceived Control: Engagement, Coping, and Development In T. L. Good (Ed.), $21^{\text {st }}$ Century Education: A Reference Handbook. Newbury Park: Sage Publications.

[37] Smith, K. E. (1997). Student teachers' beliefs about developmentally appropriate practice: pattern, stability, and the influence of locus of control. Early Childhood Research Quarterly, 12 (2), 221-243. http://dx.doi.org/10.1016/S0885-2006(97)90015-6

[38] Tschannen-Moran, M., \& Woolfolk Hoy, A., (2001). Teacher efficacy: capturing and elusive construct. Teaching and Teacher Education, 17, 783-805. http://dx.doi.org/10.1016/S0742-051X(01)00036-1

[39] Williams, M., Burden, R., (2000). Psychology for language teachers: a social constructivist approach. Cambridge University Press: Cambridge.

[40] Yesim, C.A., Sungur, S., \& Uzuntiryaki, E. (2009). Teacher self-regulation: examining a multidimensional construct. Educational Psychology 29(3), 345-356.

[41] Zimmerman, B. J. (1990). Self-regulated learning and academic achievement: an overview. Educational Psychologist, 25 (1), 3-17. http://dx.doi.org/10.1207/s15326985ep2501_2

[42] Zimmerman, B. J. (1998). Academic studying and the development of personal skill: A self-regulatory perspective. Educational Psychologist, 33, 73-86. http://dx.doi.org/10.1080/00461520.1998.9653292

[43] Zimmerman, B.J. (2000). Attaining self-regulation: A social cognitive perspective. In M. Boekaerts, P.R. Pintrich, \& M. Zeidner (Eds.), Handbook of self-regulation (pp. 13-39). San Diego, CA: Academic Press. 
[44] Zimmerman, B.J., \& Schunk, D. (2001). Reflections on theories of self-regulated learning and academic achievement. In B. Zimmerman and D. Schunk (Eds.), Self-Regulated Learning and Academic Achievement: Theoretical Perspectives (2nd Ed.) (pp. 289-307). Mahwah, NJ: Erlbaum.

Mohammad Taghi Monshi Toussi is an assistant professor of TEFL at the English Department of the Islamic Azad University, Mashhad, Iran. His main fields of interest include translation, and research on EQ and affective factors in language teaching and learning.

Afsaneh Ghanizadeh is a Ph.D candidate of TEFL at Ferdowsi University of Mashhad, Iran. She is an EFL instructor at Islamic Azad University, Mashhad Branch. She has also taught English in Language Institutes for about 14 years. She has widely published in national, international, and ISI Journals. Her major research interests include teacher education and language assessment. 